\section{Changes in cigarette consumption patterns among Brazilian smokers between 1989 and 2008}

\author{
Mudanças nos padrões de consumo de cigarros \\ dos fumantes brasileiros entre 1989 e 2008
}

\author{
André Salem Szklo 1 \\ David Levy ${ }^{2}$ \\ Mirian Carvalho de Souza 1 \\ Moysés Szklo ${ }^{3}$ \\ Valeska Carvalho Figueiredo 4 \\ Cristina Perez 5 \\ Liz Maria de Almeida 1
}

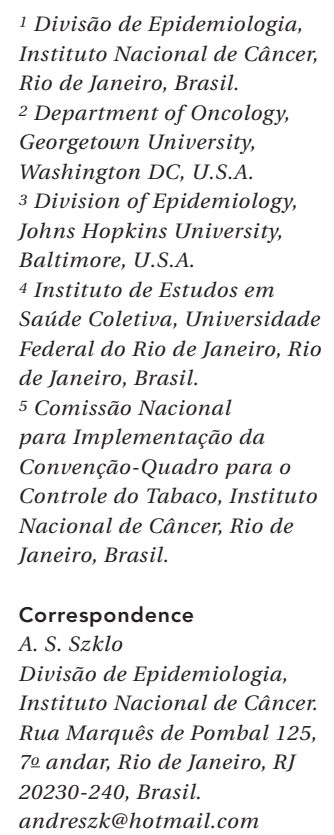

Abstract

The assessment of temporal differences in cigarette consumption may help in understanding whether a smoking population is becoming more resistant to quitting over time. We calculated absolute differences in average cigarette consumption, stratified by birth cohort and age group. Data were obtained from random samples from two Brazilian national household surveys (1989, $N=12,782 ; 2008, N=6,675)$. A linear regression model was used to adjust estimates by gender, educational level, and place of residence. Birth cohort analysis found that average daily cigarette consumption increased for individuals born after 1964 and decreased for those born before 1955 (adjusted p-values $<0.001$ ). Age-specific analysis found that the remaining smoking population aged 64 years-old or less decreased cigarette consumption between 1989 and 2008 (adjusted p-values $<0.001$ ). Brazil's anti-tobacco policy changes and rapid economic growth may be principally related to temporal changes in cigarette consumption for most age groups, rather than to a change in the relationship between age and cigarette consumption.

Smoking; Smoking Cessation; Risk Reduction Behavior; Health Policy

\section{Introduction}

The tobacco epidemic and associated disease burden are growing, particularly in low- and middle-income countries 1 . Brazil has implemented a broad set of legislative, health care, educational, and economic interventions to address tobacco use since 1986, making it a world leader in tobacco control and one of the most successful countries in reducing overall smoking prevalence 2,3. At the same time, Brazil has become one of the fastest-growing major economies in the world, thus increasing individual purchasing power 2,4 .

One of the goals of national tobacco control programs is to assess serial surveys in order to evaluate the impact of tobacco control actions on smoking behavior 5,6. Higher rates of quitting success among lighter smokers might be expected to increase the population that, on average, would smoke more heavily 6,7. However, reductions in daily cigarette consumption may be due to the influence of "environmental factors" on increased risk perceptions related to smoking intensity (e.g., restrictions on where smoking is allowed) 8 . As Brazil is a country with a longer history of tobacco prevention programs than some countries and has experienced a rapid economic growth in the last two decades 4 , the assessment of whether this country's smokers who continued to smoke reduced their average 
cigarette consumption is likely to be useful to other countries that have ratified and are implementing the WHO's Framework Convention on Tobacco Control 9.

\section{Methodology}

This study uses data from the Brazilian National Health and Nutrition Survey (PNSN) and the Global Adult Tobacco Survey (GATS-Brazil). Detailed methods for both surveys have been published elsewhere 2,3 .

\section{PNSN}

PNSN was a cross-sectional survey conducted in 1989. The primary purpose of the survey was to assess the nutritional status of the Brazilian population and its target population, comprised of all individuals living in the Brazilian territory.

A stratified and weighted probabilistic sample with two selection stages was used (census tracts and households). The PNSN total sample was 14,455 households, after excluding 3,410 vacant/nonexistant units and 55 refusals. A total of 39,969 people aged 15 years and older answered questions about tobacco use.

Two questions were used to evaluate cigarette consumption: (1) "Do you smoke cigarettes?" ("yes" or "no"); and (2) (if "yes") "How much do you smoke per day?".

\section{GATS-Brazil}

GATS-Brazil was a cross-sectional survey conducted in 2008. It was designed to obtain data on tobacco use indicators among adults 15 years and older.

A stratified and weighted probabilistic sample with four selection stages was used (municipalities, census tracts, households, and individuals aged 15 years and older). A total of 39,847 households were sampled, after excluding 9,029 vacant/nonexistant units and 2,135 refusals. A total of 39,425 individuals answered questions about tobacco use.

Information on daily cigarette consumption was based on two questions: (1) "Currently, do you smoke?" ("Daily," "Less than daily," and "Not at all"); and (2) (if "Daily" or "Less than Daily") "On average, how many cigarettes do you smoke per day (per week)?" We divided the total number of cigarettes smoked per week by occasional smokers by 7 to obtain their daily consumption.

\section{Data analysis}

Daily cigarette consumption for 1989 and 2008 was stratified by age groups expressed in 10-year intervals starting from 15 years of age. Generalized linear models using the Gaussian family were specified to obtain age-specific absolute differences in daily cigarette consumption between 1989 and 2008, adjusted simultaneously by gender, educational level, and place of residence.

In order to perform birth cohort analysis, a 5 -category variable expressed in 20 year-intervals was also created, as follows: ("selected age group in 1989" plus "selected age group 20 years older in 2008", for each category).

The Stata statistical application was used to take into account the complex sample weights (Stata Corp., College Station, USA).

\section{Results}

Our analysis of the PNSN data revealed a higher overall prevalence of cigarette smokers than was found for the GATS-Brazil data ( $31.3 \%$ vs. $17.1 \%$ ), and also a higher consumption of cigarettes per day (13.3 vs. 11.8). Males represented about $60.0 \%$ of both study samples. Most smokers in both samples lived in urban areas, increasing from 1989 (72.9\%) to 2008 (83.5\%). On average, smokers in the PNSN were younger than those in the GATS-Brazil (mean age: 37.9 vs. 42.0 ). The percentage of those with 11 years or more of education more than doubled from 1989 (11.9\%) to 2008 (24.5\%) (data not shown).

As shown in Figure 1, the number of cigarettes smoked per day increased with age to midlife and then declined with age, irrespective of year of survey. Moreover, age-specific analysis found that average daily cigarette consumption decreased from 1989 to 2008, with the exception of the "65-84 age group", irrespective of gender, educational level, and place of residence ( $p$-value $<0.001$; data not shown). Birth cohort analysis found that daily cigarette consumption increased for the youngest birth cohorts (i.e., individuals born after 1964) and decreased for the oldest birth cohorts (i.e., individuals born before 1955), irrespective of gender, educational level, and place of residence ( $\mathrm{p}$-value $<0.001$; data not shown). Cigarette consumption remained virtually unchanged among individuals born between 1955 and 1964. 

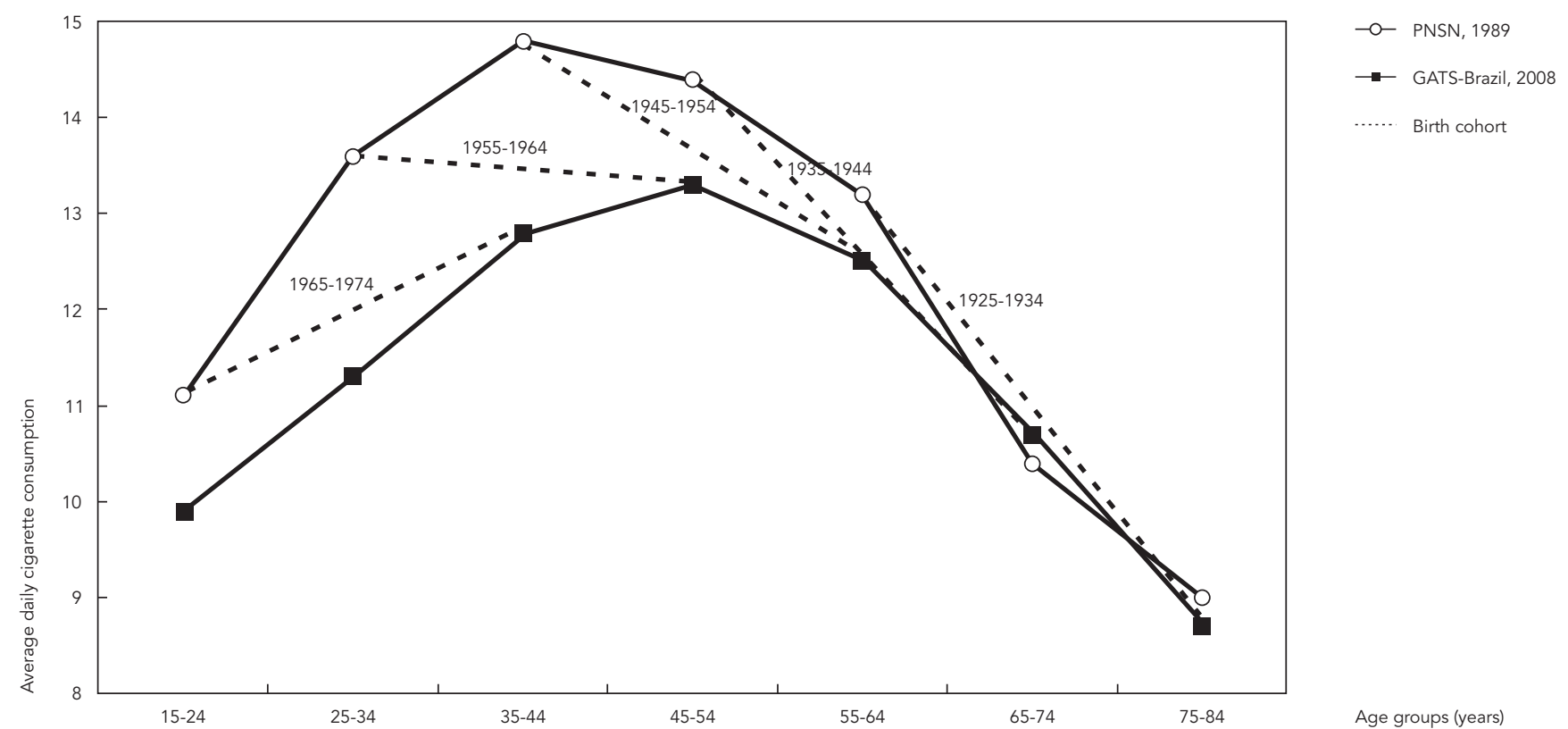

\section{Discussion}

Only the smoking population aged 15 to 24 yearsold in 1989, irrespective of gender, educational level and place of residence, increased the quantity smoked by 2008, suggesting that they may have become more addicted and, consequently, may have greater difficulty quitting in the future. Age-specific analysis comparing PNSN and GATS-Brazil suggest that the residual population of Brazilian smokers decreased their cigarette consumption over the 19-year study period.

The pattern of age-specific decline in average cigarette consumption is similar to that observed by National Health Interview Surveys conducted in the US from 1991 to 1998 and by the 1990, 1996, and 1999 California Tobacco Survey, when strong local/state tobacco control programs were being implemented 7,10. However, unlike Brazil, US birth cohort analysis revealed that younger people may not have become, on average, more addicted when they got older. Brazil's rapid economic growth since the 1990s may have attenuated the impact of higher cigarette taxes and price, especially as new cohorts of young adults gained more access to better jobs with higher earnings and were thus able to afford increased purchase of cigarettes $2,4,11$.
Although lower levels of cigarette consumption may predict higher cessation rates $2,6,7$, "environmental changes" may have reduced the degree of addiction of smokers who continued to smoke (e.g., bans on smoking in the workplaces may have inconvenienced heavy smokers more than light smokers) 7 . However, lower sensitivity in the presence of loss or threat among younger people (i.e., "optimistic bias") may have also diminished the effect of stronger tobacco control in Brazil 8,12.

Although in both selected population-based household surveys the samples were probabilistic and nationally representative, these data are subject to both survival bias (e.g., there may be a higher mortality among heavier and older smokers 6 ) and biases resulting from self-reporting (e.g., there may be an increasing tendency over time to under-report cigarette consumption due to the growing stigma associated with smoking 13 . However, data from both legal and illegal markets suggest a temporal decrease in cigarette consumption ${ }^{4}$.

The wording of the questions used to assess smoking status might have also affected the results 7 , as occasional smokers consume, on average, fewer cigarettes than daily smokers 14 . Nevertheless, intermittent smokers represents 
only a small proportion of the Brazilian smoking population 2,3. For instance, GATS-Brazil found that only $10 \%$ of current smokers were occasional smokers ${ }^{2}$, thus also showing the importance of monitoring the impact of tobacco control actions on the proportion of non-daily smokers 14 .

While the number of daily cigarettes smoked may not represent a valid measure of level of addiction 15 , heavily addicted smokers, on average, also consume more cigarettes per day 2,7. Still, surveys are needed to examine factors related to physical and psychological dependence 14,15 , as well as cessation attempts and cessation rates 7 .

\section{Resumo}

A avaliação temporal das mudanças no consumo de cigarros pode ajudar a entender se os fumantes estão se tornando mais resistentes à cessação. Calcularam-se as diferenças absolutas no consumo médio de cigarros, estratificadas por coorte de nascimento e faixa etária. Utilizaram-se dados provenientes de dois inquéritos domiciliares nacionais brasileiros (1989, $N=12.782$; 2008, $N=6.675)$. Um modelo de regressão linear foi usado para ajustar as diferenças por sexo, escolaridade e residência. A análise por coorte de nascimento mostrou que o uso de cigarros diários aumentou entre os indivíduos nascidos após 1964 e diminuiu entre aqueles nascidos antes de 1955 (valores de p ajustados $<0,001)$. A análise por faixa etária mostrou que a população remanescente de fumantes com menos de 65 anos reduziu o uso de cigarros entre 1989 e 2008 (valores de p ajustados $<0,001)$. Mudanças nas políticas antitabaco e o rápido crescimento econômico do Brasil podem estar preferencialmente relacionados a mudanças temporais no consumo de cigarros na maioria dos grupos etários, ao invés de uma mudança na associação entre idade e consumo de cigarro.

Tabagismo; Abandono do Hábito de Fumar; Comportamento de Redução de Risco; Política de Saúde

\section{Conclusion}

The overall decrease in Brazil's smoking prevalence and cigarette consumption has been described previously 2,3,4. However, this paper's results suggest that policy changes and increased earning potential may be principally related to temporal changes in cigarette consumption for most age groups, rather than to a change in the relationship between age and cigarette consumption.

\section{Contributors}

A. S. Szklo participated in data processing and analysis and as lead author in the elaboration/preparation of the article. D. Levy, M. C. Souza, M. Szklo and V. C. Figueiredo participated as consultants for data analysis and elaboration/preparation of the article. C. Perez and L. M. Almeida participated in the elaboration/preparation of the article.

\section{Acknowledgments}

Our sincere thanks is given to the technical staffs from the National Health Surveillance Agency, Tobacco Use Control Alliance, Institute of Social Medicine, Oswaldo Cruz Foundation, Brazilian National Cancer Institute, Brazilian Geographic and Statistics Institute, Health Surveillance Secretariat, Federal University of Rio de Janeiro, Pan American Health Organization, United States Centers for Disease Control, Santa Catarina State Health Secretary, CDC Foundation, and Johns Hopkins University. 


\section{References}

1. World Health Organization. Global health risks: mortality and burden of disease attributable to selected major risks. Geneva: Department of Health Statistics and Informatics, World Health Organization; 2009.

2. Brazilian National Cancer Institute. Global Adult Tobacco Survey: Brazil report. http://www.who. int/tobacco/surveillance/en_tfi_gats_2010_brazil. pdf (accessed on 22/Jan/2012).

3. Monteiro CA, Cavalcante T, Moura EC, Claro RM, Szwarcwald CL. Population-based evidence of a strong decline in the prevalence of smokers in Brazil (1989-2003). Bull World Health Organ 2007; 85:527-34.

4. Iglesias R, Jha P, Pinto M, da Costa e Silva VL, Godinho J. Tobacco control in Brazil. Health nutrition and population discussion paper. Washington DC: The World Bank; 2007.

5. Habicht J, Victora C, Vaughan JP. Evaluation designs for adequacy, plausibility and probability of public health programme performance and impact. Int J Epidemiol 1999; 28:10-8.

6. Lopez AD, Collishaw NE, Piha T. A descriptive model of the cigarette epidemic in developed countries. Tob Control 1994; 3:242-7.

7. U.S. Department of Health Services. Those who continue to smoke. Bethesda: U.S. Department of Health Services, National Institutes of Health, National Cancer Institute; 2003. (Smoking and Tobacco Control Monograph, 15).

8. De Jonge LH, Gormley M. Responses to positive and negative smoking-related images: effects of current smoking status and degree of smoking addiction. Addict Behav 2005; 30:1587-91.
9. World Health Organization. The Framework Con vention on Tobacco Control. http://www.who.int/ fctc/text_download/en/index.html (accessed on 22/Jan/2012).

10. Wakefield M, Chaloupka F. Effectiveness of comprehensive tobacco control programmes in reducing teenage smoking in the USA. Tob Control 2000; 9:177-86.

11. Instituto Brasileiro de Geografia e Estatística. An analysis of the Brazilian population social conditions. http://www.ibge.gov.br/english/estatis tica/populacao/condicaodevida/indicadoresmini mos/sinteseindicsociais2008/default.shtm (accessed on 22/Jan/2012).

12. Szklo AS, Coutinho ESF. The influence of smokers' degree of dependence on the effectiveness of mes sage framing for capturing smokers for a Quitline. Addict Behav 2010; 35:620-4

13. Gallus S, Tramacere I, Boffetta P, Fernandez E, Rossi S, Zuccaro P, et al. Temporal changes of under reporting of cigarette consumption in populationbased studies. Tob Control 2011; 20:34-9.

14. Shiffman S, Ferguson SG, Dunbar MS, Scholl SM. Tobacco dependence among intermittent smokers. Nicotine Tob Res 2012; [Epub ahead of print].

15. American Psychiatric Association. Diagnostic and statistical manual of mental disorders, fourth edition, text revision: DSM-IV-TR. Washington DC: American Psychiatric Association; 2000.

Submitted on 02/May/2012

Final version resubmitted on 30/Jul/2012

Approved on 07/Aug/2012 
